\title{
式 辞
}

\section{本学会会長 細野公男*}

1988 年 4 月に設立された情報知識学会は，本年 2008 年創立 20 周年を迎え ました。本日この 20 周年を祝う記念式典を挙行するにあたりまして，設立以 来本学会の発展のためにいろいろご尽力いただいた方々や機関に対しまして, 心からお礼申しあげますとともに，ひとことご挨拶をさせていただきます。

本学会は, データ・情報・知識・文献などを対象とする「情報学」あるいは 「情報知識学」振興の必要性に対する強い社会的ニーズに応えて, 日本学術会 議情報関係の 3 研究連絡委員会（情報学, 学術文献情報, 学術データ情報）を 中核として設立されました。設立趣意書, 設立当時の情報知識学会誌, ニュー ズレターをご覧いただければ, 学会設立に到った経緯, 当時の状況や環境を知 ることができます。米田幸夫および藤原鎮男両会長, 月見里禮次郎副会長, 小 谷正雄, 大塚明朗, 湯川康秀, 島内武彦の各先生, それに現在も本学会の重鎮 としてご活躍いただいている方々の献身的なご努力・ご尽力，さらに凸版印刷 株式会社，大日本印刷株式会社等による財政的・人的ご支援のおかげで，今日 の日を迎えることができたのです.

本学会設立の引き金となったのは, 日本学術会議において 1984 年に「情報 学」が定義されたことであります。そこでの情報学は，データ，および情報の 表現, 記述, 分類, 構造, 評価, 標準化などの基礎理論, その管理, アクセス・ 加工・流通・高次処理の方式, 情報における言語機能, 学術各分野における情 報集積活動とその利用に関する研究などとされていました。したがって, 本学 会は日本学術会議のビジョンを反映したものということができます.またデー タ，情報，知識が持つ国際性に留意して，CODATA，FID，ICSTI，ISO/TC37 や 46 などの国際機関との密接な関連のもとに種々の活動を行ってまいりまし た。現在もCODATAおよびISO/TC37とは強い絆を維持しております。

情報学あるいは情報知識学は, 学術界のみならず産業界における研究・開発 活動の根幹をなす理論・考え・アプローチ・技術を提供する，あるいはこれら の進歩・発展に寄与する, きわめて重要な分野であります。このため, 情報知 識学会は,こうした重要性に鑑みて, これまでデータ, 情報, 知識に関わる種々

\footnotetext{
* 現本学会評議員会議長
} 
のテーマ・課題を理論的, 実用的, 制度的, 学際的, 国際的等の立場から取り 上げて研究・実践し, 多くの成果をあげてきました。それらは学会誌, 研究報 告会, フォーラム, シンポジウム, 各種の部会活動に反映されています. 学会 創立 10 周年を記念して「情報学」に関する特集記事が学会誌 Vol.9 の No.1 と Vol.10の No.1に掲載されていますが，これは「情報学」への関心を高める試 みの一環として企画されたものであります.

情報知識学の振興を目的とする本学会は, データ, 情報, 知識等に関する諸 問題，たとえば，1）情報や知識の本質，蓄積・分類・検索などの基礎理論，2） データ・情報・知識の加工・分析・評価・管理などの処理，3）言語・記号，ター ミノロジーなどの表現，4）標準化，情報関連の権利・法律などの流通分野，5） 情報の管理, 知識ベース, インターネット環境下での情報受発信などの応用分 野をテーマとして研究, 発表, 実践, 意見交換などを行う会員の支援を, めざ してきました.現時点で取り上げられているテーマの例は, ホームページの「本 学会の役割」に記されております.

本学会のこれまでの活動は, 学会誌, 研究報告会, 情報知識学フォーラム, 月例懇話会, 研究部会・関西部会, メールマガジンとホームページの大きく 6 つに分けることができます.これらの活動はいずれも順調に遂行されてきまし たが，大きな変化・進展の生じたものがいくつかあります.

第一が学会誌であります. 1990 年に第 1 巻が刊行された学会誌は, 冊子体 としてまた NII の電子図書館サービス（NII-ELS）を利用して公開されてきま した。さらに学会誌の J-STAGE を利用したオープンアクセス化が決定されま したため, 2006 年 12 月末から会員, 非会員を問わず広く公開されております。 現時点でオープンアクセスの対象となっているのは, 2006 年分からでありま す。また創立 20 周年を記念して創刊号から 17 巻（2007 年）までが CD-ROM 化され, 今回の式典および研究報告会の参加者に無料配布されています.

第二がニューズレターとメールマガジンであります。1988 年に創刊され 2001 年まで合計 59 冊刊行されたニューズレターは, 2001 年以後しばらくの間 学会誌の中での記事部分として位置づけられていましたが, インターネットの 普及に合わせ装いを変えメールマガジンとして, 2007 年 7 月から再出発しま した。過去におけるニューズレターの刊行や現在のメールマガジンの発信は, 会員間での情報交換, 外部情報の会員への提供をはかるものとして，大きな役 割を担ってきました。これらニューズレターとメールマガジンは, 研究報告会 
講演論文とともに，上述の CD-ROM に収録されています.

第三は情報知識学フォーラムであります。本学会はマークアップ言語 SGML/XML の啓蒙・普及を図るため, 1997 年から 9 回にわたって SGML/XML 研修フォーラムを毎年開催してきました。この事業は成功裏に遂行されました が，SGML/XML が社会的に定着したことを踏まえて，2005 年度からこのフォ ーラムの代わりに新たな情報知識学フォーラムが開催されるようになりまし た。これは本学会の根幹であるデータ, 情報, 知識と関連する研究や実践の中 からテーマ, トピックを選んで講 演, 研究発表, 事例報告などを行うもので あります。

情報知識学会は本日から新たな一歩を踏み出したということができます.

「変化は常態である」ということばが示しますように，我々が現在生きている 時代では, データ, 情報, 知識を取り巻く環境が, 以前とは非常に異なった様 相を呈しているといえます。したがって，今後情報知識学会がこうした変化に どのように対処していくかを考え,これまで行ってきた研究と実践を時代の流 れに合わせてさらに発展させていきたいと思います.また，これまでも大阪で の研究報告会, 浜松での情報知識学セミナー, 筑波および名古屋での月例愁話 会など学会行事の地方開催がなされておりましたが, 学会活動を一層発展させ るためには,これまで以上に地方開催が必要と思われます。

これまでの活動を充実させさらに発展させるためには, 会員各位によるさら なるご支援, ご協力が不可欠であることはいうまでもありません. 今後の本学 会の活動・事業に多くの会員の方々が積極的に参加・出席・関与されますよう, 心からお願いし，ご挨拶といたします。本日は，情報知識学会設立 20 周年の 式典にご臨席，ご出席いただきありがとうございました。 